\title{
THE MAMMALS OF INDIA
}

The Fauna of British India, including Ceylon and Burma

Edited by Lt.-Col. R. B. S. Sewell. (Published under the Patronage of the Secretary of State for India.) Mammalia. Vol. I : Primates and Carnivora (in part), Families, Felidae and Viverridae. By R. I. Pocock. Pp. xxxiii $+464+31$ plates. (London: Taylor and Francis, Ltd., 1939.) $30 s$.

$\mathrm{B}^{\mathrm{L}}$ ANDFORD'S "Mammals of British India", published in 1888 and 1891, has until now been the standard work on the subject, and useful as that has been, it had for some years been regarded by zoologists as out of date, since a vast amount of additional knowledge on the subject has been gained in the last half century. A new edition that would embody the latest views on classification and the experience of sportsmen and travellers was greatly needed, and in $1923 \mathrm{Mr}$. Pocock, an eminent authority on the mammals of the world, undertook the task, little realizing the length of time that would be required owing to the vast amount of material to be handled and examined and the extent to which names of species and races required revision.

Formerly species were recognized mostly by their external appearance and local races regarded merely as varieties, whereas now careful measurements of the skulls and, where possible, other parts as well, has to be carried out. Well-defined local races are distinguished by the trinomial method of nomenclature.

That the work has been done with the utmost pains and thoroughness is clear from a perusal of the present volume, which deals with the orders Primates and Carnivora (in part). Of the former, British India possesses two species of gibbon, Hylobates hoolock and $H$. lar, these being the only representatives of the man-like apes, though the more ordinary types of monkeys are well represented by the macaques and langurs or leaf monkeys and the lemurs by the lorises.

Of the monkeys proper the author recognizes three distinct races of the rhesus in British India, the typical race occurring throughout nearly the whole of northern India and to a great extent Burma as well. This, the best known of all the monkeys as it is largely imported alive into European countries, although not regarded by the Hindus as sacred, is nevertheless left unmolested and so has become a very familiar object in native villages.

The lion-tailed macaque, also known as the wanderoo monkey, is certainly the most striking in appearance on account of the large growth of grey hair surrounding the face and the glossy black hair of the remainder of the body, but it is rare and keeps strictly to the thick forests of the Western Ghats.

Of the small lemurs, or lemuroids, the slow and slender lorises are well known, but research has shown that of the former there are no fewer than four and of the latter six distinct races. All are strictly nocturnal, sleeping bunched up in the fork of a tree by day, when they have much the appearance of the little spotted owl (Athene brama) and "the same habit of swaying the head and, when fighting, utter a similar screech". At the approach of darkness they creep forth and capture their prey "after a stealthy approach, with a lightning grab of both hands, and hold it in a tenacious grip while devouring it."

The greater part of this volume deals with the Carnivora, in which the author admits that classification is difficult. Of the Felidæ the zoologists of old grouped all in the genus Felis, with the one exception of the cheetah or hunting leopard which was distinguished by its so-called nonretractile claws; but Mr. Pocock finds that this animal is actually more nearly allied to the ordinary cats than the latter are to the lions, tigers and their near relations. He places the great cats (lions, tigers, etc.) in a separate subfamily, Pantherinæ, the more ordinary cats in that of Felinæ, including a number of genera, while the hunting leopard alone occupies the subfamily Acinonychinæ.

The lion was formerly abundant in northern India; but is now nearly extinct there, the few that remain being restricted to the Gir Forest in Kathiawar, where they are protected. The author believes that it made its way into India through Persia and Baluchistan in comparatively recent times and was not there long enough to penetrate far southwards. Its near extermination has been brought about by human persecution and not, as has often been suggested, by competition with the tiger.

This volume will surely rank as a very worthy member of a fine series.

D. Seth-Smith. 